\title{
Exploring the Relationship between Safety and Health Cost Dimensions and Accident Costs to the Employer of Urban Rail Infrastructure Projects
}

\author{
Izatul Farrita Mohd Kamar ${ }^{1,}$, Asmalia Che Ahmad ${ }^{2}$, Mohmad Mohd Derus $^{3}$, Mohd Yusof Kasiron ${ }^{4}$, and Mohd Afandi Abu \\ Bakar $^{5}$ \\ ${ }^{1}$ Centre of Postgraduate Studies, Universiti Teknologi MARA, Seri Iskandar Campus, Seri Iskandar, 32610, Perak, Malaysia \\ ${ }^{2,3}$ Faculty of Architecture Planning and Surveying, Universiti Teknologi MARA, Seri Iskandar Campus, Seri Iskandar, 32610, Perak, \\ Malaysia \\ ${ }^{4}$ Mass Rapid Transit Corporation Sdn Bhd, Jalan Dungun, Bukit Damansara, 50490 Kuala Lumpur, Malaysia \\ ${ }^{5}$ Business Management Centre, Universiti Teknologi MARA, Seri Iskandar Campus, Seri Iskandar, 32610, Perak, Malaysia
}

\begin{abstract}
The Klang Valley Mass Rapid Transit (KVMRT) System is set to be one of the mega projects in Malaysia. Many of the researches have focused on the causes of construction accident occurrences at the site. Whilst, this study focuses on the consequences (i.e., costs) of the occurrences of the accidents for the project. The work injuries create economic issues for our society. The awareness of accident costs is absent because the stakeholders always leave the matters to the insurance company. They are ignorant of the cost of an accident without realising the greatness of its impacts on the industry and the country. Therefore, this study aims to determine the relationship between accident costs and the factors influencing the accident costs of urban rail infrastructure projects to the Employer. All these factors are known as safety and health cost dimensions. For this research, the Employer, also known as a Contractor, is the person who bears the accident costs (direct and indirect costs) of the project. Multiple regression performed on the sixty-two (62) accident cases from the MRT 1 SBK (Sungai Buloh-Kajang) Line Projects. These findings could heighten the importance of the effect of an accident on the Employer's company's economics and budgeting.
\end{abstract}

\section{Introduction}

Compared to other industries, the construction industry stands unique because most of its activities often take place outdoors and under conditions that are not conducive to safety and health [1]. Different types of construction projects involve numerous types of hazards identification. The construction of the Mass Rapid Transit (MRT) system, which is the most prestige urban rail infrastructure project in Malaysia, has also been exposed to hazards. Derived from the MRT accident reports, there have been a thousand incident cases for the MRT 1 Project since the project started in 2011.

Both fatal and non-fatal accidents have a highly significant impact on the economic burden of the MRT project stakeholders. Many losses have to be incurred by the parties involved, and these include the victims, families, employers, and society [2-7].

In addition, they also affect the construction company's profit and loss statement due to damages to productivity, property, equipment, and morale as a result of delays in project completion. The costs that are related to these accidents are both indirect costs (not directly measurable) and direct costs (directly measurable, such as sick leave, medical treatment, and so on).

However, it is challenging to quantify the costs of these accidents. [8] revealed that many researchers seem challenged due to the complexity of the cost assessment and in providing companies with a reliable method for monitoring such measures [9-10]. [3] explained that none of the indirect cost evaluation methods is universal or generalisable. Thus, the employer needs some solid, quantifiable information that includes the true costs of the accidents.

Though some occupational accidents have occurred amongst the MRT Projects, no study has been carried out to measure the costs associated with such accidents to the best of our knowledge. This study bridges this gap by measuring the economic costs of occupational accidents by using quantitative approaches. Therefore, this study aims to determine the relationship between accident costs and the factors influencing the accident costs of urban rail infrastructure projects to the Employer, which are known as the safety and health cost dimensions.

\section{Determinants of S\&H Cost Parameters}

A wide variety of parameters are necessary to calculate the accident costs for the urban rail infrastructure projects. The determinants of the safety and health cost bearers, components, dimensions and categories of this study involved a further validation from the experts in verifying their suitability in the accident costs estimation of urban rail infrastructure projects.

* Corresponding author: asmalia809@perak.uitm.edu.my 


\subsection{Determinants of S\&H Cost Bearers}

The determination of the cost bearers for the safety and health cost allocationas based on the review of safety and health cost model from previous research. The cost is borne by the employer, employees, and the community/government/societies when the accident occurred at the site. The cost bearers were determined to explain in detail the parties who would bear the costs of safety and health from the project's start until completion.

There is a similarity of the classification of the cost bearers found in [11-16]. Three main stakeholders that have emerged for dealing with the safety and health cost allocations are the employer, employee, and government, for all work-related injuries in all types of business sectors.

For this research, the researcher only focused on the employer as the cost bearer. The employer, also known as the contractor, is the person who tends to bear most of the burden for minor and short-term accidents. The cost components that the contractor have to bear are the direct costs (insurable costs) and indirect costs (uninsurable costs).

\subsection{Determinants of $S \& H$ Cost Components}

[17] clarified the cost related to safety and health in the workplace into three groups; safety, non-safety, and other extraordinary costs. Other scholars have analysed the two well-known dimensions of safety and health cost, which are prevention costs and accidents costs [1820].

Therefore, safety and health costs can be classified into three (3) types which are prevention costs, accident costs, and other extraordinary costs. This research concentrated on the accident costs.

Accident costs can be categorised into the tangible and intangible costs of accidents. Tangible costs of accidents reflect the costs associated with the occurrence of an accident at work, which can be estimated or calculated using traditional cost accounting methods. On the other hand, the intangible accident costs are immeasurable in economic terms, or there are no performance indices to measure their organisational impacts such as impaired company image, low worker morale, labour disputes or market loss [21].

In Malaysia, the accident costs classified into direct costs and indirect costs [22]. The direct and indirect costs have been used in this study to suit the common terms used in the country. Direct costs are those costs that are accrued directly from the accident, which are related to the treatment of the injury and any compensation offered to workers because of being injured. The direct accident costs are typically the insurable costs that are covered by SOCSO and the insurance company, and they are quite easy to calculate. The examples are treatment at site costs, hospital costs, and property damage/repair costs.

The indirect costs are the costs which are not measurable in economic terms or for which there are no performance indices to measure their impacts on the organisation. These costs are the consequences of an accident that can be costly. They are more difficult to calculate and tend not to be insurable [21].

There are a few different definitions of indirect costs (uninsured costs); but in general, they are regarded as comprising all of the cost items that are not covered by the worker's compensation insurance. The indirect costs of accidents comprise of several components, such as loss due to the injured worker, inefficiency of the worker who had just recovered from an injury upon resuming work, medical expenses, fines and legal expenses, the employees' productivity, damaged equipment or plants, to damaged materials, and idle machinery or equipment.

\subsection{Determinants of S\&H Cost Dimensions}

The factors influencing the safety and health costs in the construction projects are known as the dimensions that influence the accident costs (direct and indirect costs). Each of the cost dimensions grouped into several categories based on the previous studies. The dimensions are reviewed and summarised in Table 1.

Table 1. Summary of Safety and Health Cost Dimensions \& Categories

\begin{tabular}{|c|l|}
\hline Author & \multicolumn{1}{|c|}{ S\&H Cost Dimensions } \\
\hline$[17]$ & Accident rate (phase of project implementation) \\
\hline$[23]$ & Accident frequency rate, Project hazard level \\
\hline$[8]$ & $\begin{array}{l}\text { Type of accident, Number of lost days, and } \\
\text { Number of days of temporary assignment }\end{array}$ \\
\hline$[24]$ & Event of injury \\
\hline$[15]$ & $\begin{array}{l}\text { Direct costs-severity of the incident, Indirect } \\
\text { Costs-duration of absence and nature }\end{array}$ \\
\hline$[13]$ & $\begin{array}{l}\text { Days of absence from work (medical leave), } \\
\text { Average number of days admitted in general } \\
\text { ward, Number of days and income lost }\end{array}$ \\
\hline$[25]$ & $\begin{array}{l}\text { Number of days lost, Temporary assignment and } \\
\text { productivity }\end{array}$ \\
\hline$[26]$ & Length of hospital stay in a government hospital \\
\hline$[27]$ & Average Length of Stay in Hospital (Days) \\
\hline$[16]$ & Zone of accident \\
\hline
\end{tabular}

\section{Methodology}

The respondents, who were the safety personnel at the KVMRT project were required to answer a questionnaire based on the accident cases which had occurred in their projects. The respondents were required to provide information or estimate the accident costs components based on the questions in the questionnaire.

This study conducted on the work package contractors (WPC) from the viaduct (guideway) package of the KVMRT Sungai Buloh Kajang (SBK) Line Project. Eight numbers of WPC, which were representative of eight projects (V1-V8) which selected as the sample of the study. From the above projects, 68 of the reportable accident cases, which were Class 1 (Fatality), Class 2 (Permanent Disability), Class 3 (Temporary Disability) and Class 8 (Dangerous Occurrence), occurred during the construction of those 
projects. The respondents returned only a total of 62 questionnaires.

Multiple regression analysis is used to analyse the relationship between variables using the Statistical Package for Social Sciences (SPSS) software. The log transformation is used for continuous data to decrease the variability of the data and make the data conform more closely to the normal distribution. For categorical data, multiple regression used with dummy variables. This robust analysis was applied in this study to determine the most significant variables affecting the accident costs.

Five tests were performed to ensure the reliability and explainability of the MRA models, namely, the pairwise correlation matrix, correlation variance inflation factors (VIF), a coefficient of determination $\left(\mathrm{R}^{2}\right)$, F-test, and T-test.

\subsection{Measurements of the Major Variables}

\subsubsection{Safety \& Health Cost Components}

The significant variables included the safety $\&$ health cost components when the accident occurred, which were the medical treatment costs, hospital costs, damage/repair costs, and fine costs.

Whilst for the indirect accident costs, there were twelve cost components which were the accident costs, replacement costs, legal $\&$ administrative costs, schedule costs, productivity costs, work in progress costs, recruiting costs, uninsured medical costs, management costs, corrective action costs, ex-gratia costs, and reputation/company image costs.

\subsubsection{Safety \& Health Cost Dimensions \& Categories}

Based on the literature review, the five major variables for the direct safety and health cost componentswere identified. The types of accident classification (AC), the day of the stop work order (SWO), the day of the medical leave (ML), the day of the hospital admission (HA) and the locations of the body's injuries (LBI) should include the scales dealing with estimating the accident costs which are described in Table 2.

Table 2. Major Variables of Accident Costs Components, Dimensions and Categories

\begin{tabular}{|l|l|l|}
\hline $\begin{array}{c}\text { Safety \& Health Cost } \\
\text { Components }\end{array}$ & $\begin{array}{c}\text { S\&H Costs } \\
\text { Dimensions }\end{array}$ & \multicolumn{1}{|c|}{$\begin{array}{c}\text { S\&H Costs } \\
\text { Categories }\end{array}$} \\
\hline Direct Accident & & 1= Class 1 \\
\hline$\underline{\text { Costs : }}$ & (AC) & (Fatality), \\
\hline 1) Medical Treatment & & 2= Class 2 \\
at Site Costs & & (Permanent \\
2) Hospital Costs & & Disability), \\
3) Damage/Repair & & $3=$ Class 3 \\
& Costs & (Temporary \\
4) Fine Costs & & Disability), \\
& & 4= Class 8 \\
& & (Dangerous \\
& & Occurrence) \\
\hline
\end{tabular}

\begin{tabular}{|c|c|c|}
\hline $\begin{array}{l}\text { Indirect Accident } \\
\text { Costs: }\end{array}$ & (SWO) & $\begin{array}{l}1=0-14 \text { days } \\
2=15-30 \text { days } \\
3=>30 \text { days }\end{array}$ \\
\hline $\begin{array}{l}\text { Costs } \\
\text { 2) Replacement Costs } \\
\text { 3) Administration } \\
\text { Costs } \\
\text { 4) Schedule Costs }\end{array}$ & (ML) & $\begin{array}{l}1=0-3 \text { days } \\
2=4-7 \text { days, } \\
3=8-14 \text { days, } \\
4=15-30 \text { days } \\
5=>30 \text { days }\end{array}$ \\
\hline $\begin{array}{l}\text { 5) Productivity Loss } \\
\text { Costs } \\
\text { 6) Work in Progress }\end{array}$ & (HA) & $\begin{array}{l}1=0-20 \text { days } \\
2=21-30 \text { days } \\
3=>30 \text { days }\end{array}$ \\
\hline $\begin{array}{l}\text { Costs } \\
\text { 7) Compensation to } \\
\text { Victim/Ex-Gratia } \\
\text { Costs } \\
\text { 8) Recruiting Costs } \\
\text { 9) Uninsured Medical } \\
\text { Costs } \\
\text { 10) Management Costs } \\
\text { 11) Corrective Action } \\
\text { Costs } \\
\text { 12) Reputation Loss } \\
\text { Costs }\end{array}$ & (LBI) & $\begin{array}{l}1=\text { No injury, } \\
2=\text { Upper limb, } \\
3=\text { Head, } \\
4=\text { Trunk, } \\
5=\text { Lower Limb, } \\
6=\text { Multiple, } \\
7=\text { Neck }\end{array}$ \\
\hline
\end{tabular}

\section{Results and Discussions}

\subsection{Pairwise Correlation Matrix}

The pairwise correlation matrix is useful to predict a relationship of variables between two sets of data involving dependence [28]. This test also used as the first step to detect multicollinearity. The multicollinearity test is to see the correlation between each explanatory variable. It is statistically independent to another if the results show no relationship between the explanatory variables [29].

If the explanatory variables are highly correlated, it will lead to an unreliable and unstable estimator. Table 3 shows that there were no variables that had the collinearity index above 0.8 . According to [30], there are no guidelines on which variables are causing a problem when a pair of variables is shown to have a high collinearity index above 0.8 .

Table 3. Correlation Indices

\begin{tabular}{|c|c|r|r|r|r|r|}
\hline & \multicolumn{1}{|c|}{ AC } & \multicolumn{1}{c|}{ SWO } & \multicolumn{1}{c|}{ ML } & HA & LBI & TAC \\
\hline AC & $\mathbf{1}$ & & & & & \\
\hline SWO & $.333^{* *}$ & $\mathbf{1}$ & & & & \\
\hline ML & .055 & -.063 & $\mathbf{1}$ & & & \\
\hline HA & $.333^{* *}$ & -.016 & $.261^{*}$ & $\mathbf{1}$ & & \\
\hline LBI & $.416^{* *}$ & -.038 & .005 & $.432^{* *}$ & $\mathbf{1}$ & \\
\hline TAC & $.449^{* *}$ & .218 & .048 & .175 & $.405^{* *}$ & $\mathbf{1}$ \\
\hline
\end{tabular}

\subsection{Variance inflation factors (VIF)}

This study also relied on the VIF values of the independent variables as a procedure for a double check to detect multicollinearity. There are two opinions in indicating high multicollinearity using VIF values. First, [31] stated that a VIF value below 10 indicates low multicollinearity, and [32] and [33] stated that a VIF value below 5 indicates low multicollinearity. 
However, according to [30], there is no theoretical basis for choosing which VIF value (either below 10 or below 5) to use to detect multicollinearity. Therefore, this study adopted the value of 10 in detecting suspicious variables regarding multicollinearity. Table 4 indicates that the VIF values for all of the regressors were below five indicating that there was no serious multicollinearity amongst them.

Table 4. Summary of the Multicollinearity Test

\begin{tabular}{|c|l|c|}
\hline Dependent Variable & Independent Variable & VIF \\
\hline Total Accident & (AC) & 1.480 \\
Costs (TAC) & (SWO) & 1.188 \\
\cline { 2 - 3 } & (ML) & 1.096 \\
\cline { 2 - 3 } & (HA) & 1.388 \\
\cline { 2 - 3 } & (LBI) & 1.435 \\
\hline
\end{tabular}

\subsection{The coefficient of Determination $\left(R^{2}\right)$}

This statistic indicates the percentage of the variance in the dependent variable that the independent variables explain collectively. It measures the strength of the relationship between the model and the dependent variable on a convenient $0-100 \%$ scale.

As indicated in Table 5, the $\mathrm{R}^{2}$ for the MRA model of accident costs was .446. It means that the independent variables of the accident costs explained $44.6 \%$ of the variation in the dependent variable.

Table 5. Summary of the Basic Statistics of $\mathrm{R}^{2}$

\begin{tabular}{|c|c|c|c|}
\hline MRA Model & $\mathrm{R}^{2}$ & Adj R $^{2}$ & Sig \\
\hline Total Accident Costs & .446 & .396 & .000 \\
\hline
\end{tabular}

\subsection{F-test}

The results of the ANOVA test shown in Table 6. The results show that the $\mathrm{p}$-value for the total accident costs was 0.000 , which was less than the alpha level of 0.05 . Thus, it can be said that this model provides a better fit than the intercept-only model. A regression model that contains no predictors is also known as an intercept-only model.

Table 6. ANOVA Test Results of the Total Accident Costs

\begin{tabular}{|c|c|c|}
\hline MRA Model & F-Value & Sig. \\
\hline Total Accident Costs & 9.004 & .000 \\
\hline
\end{tabular}

\subsection{T-test}

The significant variables for the MRA model shown by the t-test result (Table 7). Out of the five variables analysed for the total accident costs, three variables were significant. It shows that the total accident costs (direct $\&$ indirect costs) were significantly affected by the $\mathrm{AC}$ $(p<0.05)$, SWO $(p<0.01)$, and LBI $(p<0.01)$. These variables had strong relationships with the total accident costs incurred by the employer.

The results reveal that the total accident costs were affected by the different types of accident classification
(AC) $(\beta=.493)$, the number of days for the stop work order (SWO) $(\beta=1.827)$ and the different locations of the body's injuries (LBI) $(\beta=.714)$.

This finding further reinforced the notion that the costs of an accident incurred by the employer are related to those in previous studies. [3] revealed that the accident category and the number of days lost are factors which should include in the calculations of indirect accident costs. Whilst [13] concluded that the number of days admitted to the hospital is related to the severity of the accident in measuring the economic costs of an occupational accident.

Table 7. The t-values of the MRA Model

\begin{tabular}{|c|l|c|c|c|}
\hline $\begin{array}{c}\text { Dependent } \\
\text { Variable }\end{array}$ & $\begin{array}{c}\text { Independent } \\
\text { Variable }\end{array}$ & Coefficient & t-value & Sig. \\
\hline \multirow{2}{*}{$\begin{array}{c}\text { Total } \\
\text { Accident } \\
\text { Costs }\end{array}$} & $(\mathrm{AC})$ & .493 & 2.322 & .024 \\
\cline { 2 - 5 }$(\mathrm{SWO})$ & 1.827 & 3.605 & .001 \\
\cline { 2 - 5 }$(\mathrm{MTAC})$ & $(\mathrm{ML})$ & .068 & .436 & .665 \\
\cline { 2 - 5 } & $(\mathrm{HA})$ & -.450 & -.822 & .415 \\
\cline { 2 - 5 } & $(\mathrm{LBI})$ & .714 & 2.773 & .008 \\
\hline
\end{tabular}

Similar findings have been observed in other studies. $[15,25,26]$ also revealed that all these factors were significantly influential to the total accident costs (direct and indirect costs). Moreover, [24] described the costs of occupational injuries that presented as three influential factors, which were the industry level, worker characteristics, and event of the injury.

However, these results are in contrast to the Occupational Safety and Health (OSH) Calculator developed by the Department of Occupational Safety and Health. The calculator identified a different factor that was significantly affected by the accident costs, which was the zone (location of accident) factor [16].

\section{Conclusion}

This paper provides valuable insight into the relationship between accident costs and the safety and health cost dimensions. It can be concluded that the types of accident classifications, the day of the stop work order and location of the body's injury were significantly affected by the total accident costs. These findings could facilitate an employer in estimating the accident costs and heighten the importance of the effect of an accident on the company's economics and budgeting. Also, it could enrich awareness in improving preventive measures for a construction project. A reliable estimate of the cost of accidents on construction projects may assist an employer to plan investment in safety measures in a more appropriate manner.

This research was funded in part by grants from the Fundamental Research Grant Scheme (FRGS) under the Malaysian Ministry of Higher Education (MOHE). Project code: FRGS/1/2016/SSI11/UITM/03/1. 


\section{References}

1. M. S. Misnan and A. H. Mohammed, Development of safety culture in the construction industry: A conceptual framework, in 23rd Annual ARCOM Conference, 3-5 September 2007, 2007, no. September, pp. 13-22. (2007).

2. N. V. Davies and P. Teasedale, The Costs to the British Economic of Work Accidents and Work Related Health, Heal. Saf. Exec., (1994).

3. R. Jallon, D. Imbeau, and N. De Marcellis-Warin, Development of an indirect-cost calculation model suitable for workplace use, J. Safety Res., vol. 42, no. 3, pp. 149-164, (2011).

4. D. L. Goestsch, Construction Safety and Health, Second. New Jersey, USA: Pearson Education, 2013.

5. A. Asan, Developing an Accident Causation Model for Accident Prevention At Building Construction Sites.

6. E. Pellicer, G. I. Carvajal, M. C. Rubio, and J. Catal, A method to estimate occupational health and safety costs in construction projects, KSCE J. Civ. Eng., vol. 18, no. 7, pp. 1955-1965, (2014).

7. Y. Feng, S. Zhang, and P. Wu, "Factors influencing workplace accident costs of building projects," Saf. Sci., (2015).

8. R. Jallon, D. Imbeau, and N. De Marcellis-Warin, A process mapping model for calculating indirect costs of workplace accidents, J. Safety Res., vol. 42, no. 5, pp. 333-344, (2011).

9. A. Gavious, S. Mizrahi, Y. Shani, and Y. Minchuk, The costs of industrial accidents for the organization: Developing methods and tools for evaluation and cost-benefit analysis of investment in safety, J. Loss Prev. Process Ind.,vol.22, no.4, pp. 434-438, (2009).

10.P. Dorman, The Economics of Safety, Health, and Well-Being at Work: An Overview, InFocus Progr. SafeWork, Int. Labour Organ. Evergr. State Coll., pp. 1-41, (2000).

11. M. V. P. Aaltonen, E. Uusi-Rauva, J. Saari, M. AnttiPoika, T. Räsänen, and K. Vinni, The accident consequence tree method and its application by realtime data collection in the Finnish furniture industry, Saf. Sci., vol. 23, no. 1, pp. 11-26, (1996).

12. V. Hrymak and J. D. Pérezgonzález, The costs and effects of workplace accidents Twenty case studies from Ireland, A Rep. Heal. Saf. Auth., no. March, (2007).

13. R. T. Shalini, Economic cost of occupational accidents: Evidence from a small island economy, Saf. Sci., vol. 47, no. 7, pp. 973-979, (2009).

14. S. Executive, Costs to Britain of workplace fatalities and self-reported injuries and ill health , 2013 / 14, pp. 1-25, (2013).

15. C. November, The Cost of Work-related Injury and Illness for Australian Employers, Workers and the, no. November, (2015).

16.KLIACS_JKKP, Kajian Mengenai Kos Kemalangan Di Tempat Kerja Bagi Sektor Pembinaan, (2013).

17. M. López-Alonso, M. P. Ibarrondo-Dávila, M. C. Rubio-Gámez, and T. G. Munoz, The impact of health and safety investment on construction company costs, Saf. Sci., vol. 60, pp. 151-159, (2013).

18. E. W. L. Cheng, N. Ryan, and S. Kelly, Exploring the perceived influence of safety management practices on project performance in the construction industry, Saf. Sci., vol. 50, no. 2, pp. 363-369, (2012).

19. G. E. Gurcanli, S. Bilir, and M. Sevim, Activity based risk assessment and safety cost estimation for residential building construction projects, Saf. Sci., vol. 80, pp. 1-12, (2015).

20. J. E. LaBelle, What do accidents truly costs? Determining total incident costs, Prof. Saf., vol. 45, no. 4, pp. 38-42, (2000).

21. M. 1. Gosselin, No Title, Anal. des Avantag. des coûts la santé la sécurité au Trav. en Entrep. Développement l'outil d'analyse, (2004).

22. KLIACS_JKKP 2013 Kajian Mengenai Kos Kemalangan Di Tempat Kerja Bagi Sektor Pembinaan, pp. 1-77, (2008).

23. Y. Feng, Mathematical Models for Determining the Minimum Level of Voluntary Safety Investments for Building Projects, J. Constr. Eng. Manag., vol. 141, no. 7, p. 4015015, (2015).

24. G. M. Waehrer, X. S. Dong, T. Miller, E. Haile, and Y. Men, Costs of occupational injuries in construction in the United States, Accid. Anal. Prev., vol. 39, no. 6, pp. 1258-1266, (2007).

25. F. J. Forteza, J. M. Carretero-Gómez, and A. Sesé, Occupational risks, accidents on sites and economic performance of construction firms, Saf. Sci., vol. 94, pp. 61-76, (2017).

26. K. L. Tang, B. C. Wimmer, M. E. Akkawi, L. C. Ming, and B. Ibrahim, Research in Social and Administrative Pharmacy Incidence and pattern of medication errors in a general paediatric ward in a developing nation, Res. Soc. Adm. Pharm., pp. 3-5, (2017).

27. Ministry of Health Malaysia, Health Indicators 2017: Indicators for Monitoring and Evaluation of Strategy Health for All, (2017).

28. J.W. Creswell, Educational Research:Planning, Cnducting, and Evaluating Quantitative and Qualitative Research (4th Edition). Pearson Education, (2012).

29. S. T. Brooks and Chris, Real Estate Modelling and Forecasting, (2010).

30. S. Ismail, A. Hamid, and M. Iman, Testing For the Existence of Housing Sub-Markets In Penang, Malaysia, Malaysian J. Real Estate, vol. 4, no. 1, (2009).

31. R. M. O'brien, No TitleA Caution Regarding Rules of Thumb for Variance Inflation Factors. Quality \& Quantity, vol. 41, no. 5, pp. 73-90, (2007).

32. D. Rosiers, François, M. Thériault, P.Y. Villeneuve, Sorting out Access and Neighbourhood Factors in Hedonic Price Modelling., J. Prop. Invest. Financ., vol. 18, no. 3, pp. 291-315, (2000).

33. Thériault, Marius, François Des Rosiers, Paul Villeneuve, Y.K, Modelling Interactions of Location with Specific Value of Housing Attributes, Prop. Manag., vol. 21, no. 1, pp. 25-62, (2003). 